\title{
Audit Quality and Earnings Management among Nigerian Listed Deposit Money Banks
}

Olabisi Jayeola*, Agbatogun Taofeek 0 , and Akinrinlola Toluwalase 0

Department of Accounting, College of Management Sciences, Federal University of Agriculture, Abeokuta, Nigeria

\begin{abstract}
The incessant failure of Nigerian deposit money banks has raised queries on audit quality in the Nigerian banking sector. Hence, the study examined relationship between Audit Quality and Earnings Management in Nigerian listed deposit money banks. The study adopted a longitudinal research design and secondary data covering a period of 2005-2014 were collected. The population of the study comprised fifteen (15) deposit money banks listed on Nigerian Stock Exchange as at 2016, out of which six (6) banks were randomly selected resulting in 60 observations. Panel data technique was employed, while fixed and random effects model were used for estimation. Descriptive Statistics, Pearson correlation coefficient and simple pooled OLS regression analysis were used for analysis to determine possible link between the variables identified. The results of the study showed that a significant positive relationship existed between joint audit and earnings management $(\beta 1=1.054533 ; t=2.34$; and $p=0.0023<0.05$ ), which implies that a change to joint audit from single audit increases earnings management. Also, a significant negative relationship existed between audit specialization and earnings management $(\beta 2=-0.0302366 ; t=-2.07$; and $p=0.043<0.05$ ), which implies that every unit increase in audit specialization decreases earnings management. Furthermore, a significant positive relationship existed between audit independence and earnings management ( $\beta 4=$ is $0.6010025 ; t=4.96 ; p$-value at $0.008<0.05$ ). However, there was an insignificant negative relationship between audit tenure and earnings management $(\beta 2=-0.0078915 ; t=-0.12 ; p=0.906>0.05)$. The study concluded that lengthy audit tenures were mechanisms adopted by banks' managers to influence auditors' objectivity in the course of audit assignment. Therefore, the study recommended that lengthy audit tenure be discouraged.
\end{abstract}

Keywords: Joint audit; Audit specialization; Audit independence; Audit tenure; Audit quality

\section{Introduction}

In recent times, the call for reliable financial reporting has gained prominence in Nigeria and global economy at large. The capability or incapability of banks to effectively fulfill intermediate mandate has been the crux of many financial crises. Mediating between the surplus and deficit units within the economy expedites distribution of national savings, thereby improving investments and national output. In 2005, the Central Bank of Nigeria mandated every Nigerian bank to increase capital base from 2 billion naira to 25 Billion Naira in order to enhance competitiveness in the international market. Noteworthy capital market expectations were raised and banks were under pressure to achieve survival and generate higher returns to shareholders. This pressure from the Central Bank of Nigeria has occasioned banks falsifying accounts, inflating earnings and capital. The need for reliable reports has led to statutory audit that provides independent authentication of financial statements prepared by banks' directors.

Auditors are instructed to report financial misdemeanors in company's accounts to increase transparency and accountability through fraud detection. Earnings are made up of accruals and cash items and accruals are basically controlled by company's stewards. Management can bloat performance of company and future earnings predictions through manipulation of accruals resulting in earnings management. Financial reports contain accounting information which different users use to appraise firm's performance. Investors use cash flow statement to make investment decisions thereby creating room for highly motivated and intelligent management teams to manipulate the real economic operations to influence the true picture of a company's cash flow from operations. Since accrual accounting measures the performance of company by recognizing economic events irrespective of when transactions occur. Earnings management is therefore, discovered by conducting tests on the components of accrual assumed to be at the managerial discretionary accruals thereby revealing information asymmetries. Accounting scandals experienced in the last few years have affected the regulators' trust of financial statements. This scandal and its consequent results are reasons for drawing attention to quality and reliability of financial statements in the banking sector. Therefore, the absence of investors' confidence in the reported earnings influence the financial market because investors are major players in ensuring availability of capital to support the economic system. Given the above state, this study seeks to assess the effect of audit quality on earnings management in Nigerian listed deposit money banks. The broad objective of this study is to identify relationship between audit quality and earnings management of Nigerian listed money deposit banks while to assess relationship among joint audit, auditor specialization, auditor independence and audit tenure on the earnings management in the listed deposit money banks in Nigeria would need to established.

\section{Literature Review}

\section{Concept of earnings management and quality}

Earnings management and earnings quality are closely related concepts and researchers generally agree that highly managed earnings

${ }^{*}$ Corresponding author: Olabisi Jayeola, Department of Accounting, College of Management Sciences, Federal University of Agriculture, Abeokuta, Nigeria, Tel: 08033549625; E-mail: jayeolaolabisi@yahoo.com

Received May 10, 2017; Accepted June 03, 2017; Published June 15, 2017

Citation: Jayeola O, Agbatogun Taofeek O, Akinrinlola Toluwalase O (2017) Audit Quality and Earnings Management among Nigerian Listed Deposit Money Banks. Int J Account Res 5: 159. doi:10.4172/2472-114X.1000159

Copyright: ( 2017 Jayeola O, et al. This is an open-access article distributed under the terms of the Creative Commons Attribution License, which permits unrestricted use, distribution, and reproduction in any medium, provided the original author and source are credited. 
indicate poor audit quality [1,2]. Many factors contribute to earnings quality, hence the absence of earnings management is lacking to assume earnings quality [1]. Earnings quality is a broader term that scientists interpret differently, depending on the specific situation is applied. McNichols [3] described earnings quality as elusive in the sense that extant literature only identifies diverse characteristics associated with it [4]. Dechow et al. [5] believed that earnings quality provide more information about the features of a firm's financial performance that are relevant to specific decisions made in the organizations. Simply put, whether an earnings quality is regarded as of high or low quality depends on the extent of information presented about a firm's financial performance. High earnings quality implies less information asymmetry, and investors and other stakeholders make more appropriate decisions, based on a more realistic view of the company performance. Low earnings quality implies the presence of earnings management and investors and other stakeholders become misinformed and misguided.

In the light of this, accruals exhibit different kinds of problems since managers' aim at making company appear desirable and attractive, they tempt to use discretions to handgrip accruals to signal private information or manipulate earnings. Various researchers claim that abnormal accruals measure the degree of earnings management, which is seen as a dimension of earnings quality.

\section{Review of empirical studies}

The debate on the relationship between audit quality and earnings management is unending because of inconsistent empirical findings from singularity of interest. While some empirical studies have reported the abilities of audit quality to significantly constrain earnings management [6-8] others have reported otherwise.

Joint Audit and audit quality: Holm and Thinggaard [9] examined whether joint audit impacts audit quality in the Danish setting. The sample comprises non-financial companies listed on the Copenhagen Stock Exchange (CSE) at the time of joint audit abolishment. They found insignificant coefficients on audit quality measures (abnormal accruals), suggesting that joint audit is not better able to constrain earnings management than single audits. Lesage et al. [10] also examined whether joint audit impacts audit quality in the Danish setting. Their findings showed insignificant coefficients on the abnormal accrual measures for either period. Hence, these confirm that joint audits do not have impact on audit quality, as measured by the level of abnormal accruals. In a study carried out in Denmark, Zerni et al. examine the impact of the voluntary joint audit on audit quality in the Swedish setting for the 2001-2007 period. The authors considered a sample of listed non-financial Swedish companies and a sample of privately held firm Swedish. The findings suggested that companies opting voluntarily for joint audits have a higher degree of earnings conservatism, lower abnormal accruals (both are proxies for audit quality), better credit ratings and lower risk forecasts of becoming insolvent within the next few years than other firms (both are proxy measures for perceived audit quality). Thus, the joint audit decision might be driven by minority shareholders who prefer a higher degree of conservatism in the firm's accounting decisions.

Also in Swedish context, Zerni et al. examine whether corporate governance devices including joint audit can effectively mitigate 'entrenchment discounts. Zerni et al. defined the entrenchment problem as the possibility that large shareholders opt to use their power to expropriate minority shareholders by taking actions and investment decisions serving their own interests, leading to suboptimal outcome for minority shareholders. Consequently, entrenchment discounts arise when the non-controlling shareholders expect to face a potential expropriation by the controlling shareholders and discount the share price accordingly.

In a study conducted by Pouraghajan et al. [11] audit firm size was used to measure audit quality and the absolute value of discretionary accruals was used as an indicator of earnings management. Also, the modified Jones model proposed by Dechow et al. [12] was used to calculate discretionary accrual. The results indicate that auditing the financial statements of companies by large audit firms (high audit quality) is not effective in reducing the manipulation of discretionary accruals by managers and cannot control the opportunistic behaviours of managers. The obtained results are consistent with the research results of Jeong and Rho [13] and Abdul and Ali [14], Memis and Cetenak [15] but, contrary to research results of Chen et al. [16], Becker et al. [17] and Zgarni et al. [18]. provide evidence that auditors' industry specialization affects negatively the accruals earnings management, as documented in prior studies $[17,19]$. The results show a negative and significant influence of the auditor size on reducing accruals earnings management.

Auditor specialization and audit quality: The importance of industry specialized auditors is attributable to the research findings that auditor industry expertise is associated with better auditor performance and higher audit quality. Low [20] examines the effects of industry specialization on auditors' risk assessment and auditplanning decisions and finds that industry knowledge improves audit risk assessment and influences the perceived quality of audit-planning decisions. One stream of literature argues that auditor industry expertise will help constrain earnings management thereby increasing earnings quality. For example, Balsam et al. [21] find that clients of industry specialist auditors have lower discretionary accruals and higher earnings response coefficient than clients of non-specialist auditors, suggesting that auditor industry specialization improves earnings quality. Overall prior empirical evidence shows that auditor industry specialization seems to be positively associated with different proxies of audit quality.

Auditor independence and audit quality: Aderibigbe [22] viewed independence as an emotive word serving as a banner for freedom, integrity and all that is good. Louwers et al. [23] expressed independence as a mental attitude and physical appearance which portrays the auditor as being uninfluenced by others in judgment and decision. This can be sustained by avoiding financial connection that makes it appear that the wealth of the auditor depends on the outcome of the audit and management connections that makes the auditor appear as if he is involved in management decisions. As a key ingredients of audit quality. Gray and Manson [24] and Hayes et al. [25] described independence as a position required in other to take an unbiased viewpoint in the performance of audit tests, analysis of results and attestation in the audit report. Despite all the definitions, and descriptions of auditor independence, Whittington and Pany [26] concluded that auditor independence is relative and not absolute. Adeyemi and Olookere suggested in their study that audit and nonaudit fees threatened auditors' independence in Nigeria.

Auditor tenure and audit quality: The question of whether audit firm tenure impacts audit quality has long been one of the major issues concerning auditing regulations. Some believe that lengthy auditor tenure undermines independence and objectivity, while others believe that long tenure increases auditor knowledge and competence. Mgbame et al. [27] revealed a negative relationship between auditor tenure and 
audit quality; though the relationship was not significant. Siregar et al. [28] carried out their research in the Indonesian environment where regulators had made it compulsory to rotate the appointments of public accountants every three years and the appointment of public accounting firms every five years. Their results showed that mandatory auditor rotation did not increase audit quality; and that shorter audit tenure (both partner and firm level) did not also increase audit quality.

In a high tax alignment countries financial statements are taken to be the basis for taxation and in fact part of the tax statement, tax authorities are expected to rigorously examine financial statements. Myers et al. [29] studied the relation between auditor tenure and earnings quality, using the dispersion and the magnitude of both raw and absolute abnormal accruals and current accruals as proxies for earnings quality. Their conclusions suggest that higher earnings quality is correlated with longer auditor tenure. Their interpretation of these results is that, under the research environment, the longer-tenure auditors tend to place greater constraints on extreme management decisions in the reporting of earnings.

\section{Methodology}

This study employed a longitudinal research design to assess the relationship between Audit Quality and Earnings Management in listed deposit money banks in Nigeria. The population for the study comprised fifteen deposit money banks listed on the Nigerian stock exchange as at $31^{\text {st }}$ of December, 2016. This study covered a period of ten years (2005-2014) as it collides with events significant to this study which include the mandatory increase in the capital base of banks, Nigerian banking consolidation and global economic meltdown, events which could necessitate competition for fresh capital by companies listed on the Nigerian Stock Exchange which could have encouraged banks to participate in earnings management. Random sampling is the technique employed in selecting six of the deposit money banks listed on the Nigerian Stock Exchange as it involves examination of a permanent sample from which information would be collected several times over a period of time. The six banks selected include First Bank, Guaranty Trust Bank, Zenith Bank, Stanbic IBTC Bank, Diamond Bank and First City Monument Bank. The study used secondary data extracted from published annual reports and accounts of the sampled banks and the Nigerian Stock Exchange fact book for the relevant years. Beaver and Engel developed a model for measuring allowance for loan loss. They estimated the non-discretionary component of the allowance for loan loss by using a set of information variables, including nonperforming loans and net loan charge-offs, that reflect probable loan losses. The discretionary component is then estimated as the difference between the total provision and the estimated nondiscretionary components. Beaver and Engel suggest that this reflects the amount of additional adjustments to the allowance account based on a variety of discretionary motives. The Beaver and Engel (1996) model was adopted in this research. The model is as stated in 3.1 below:

$$
L L P_{i t}=\beta_{0}+\beta_{1} C O_{i t}+\beta_{2} L O A N_{i t}+\beta_{3} N P L_{i t}+\beta_{4} N P L_{i t+1}+\varepsilon_{i t}
$$

Where:

$\mathrm{ALL}_{\mathrm{it}}=$ Allowance for loan losses

$\mathrm{CO}_{\mathrm{it}=}$ Net charge-offs

LOAN $_{\text {it }}=$ Loans outstanding

$\Delta \mathrm{NPL}_{\mathrm{it}+1}=$ One-period-ahead change in nonperforming loans

$\varepsilon i t=$ Regression residual reflecting estimate of the discretionary portion of all the residual from this equation $\left(\varepsilon_{\mathrm{it}}\right)$ is taken to be an estimate of discretionary component of allowance for loan losses. Given the measure of Earnings Management from model one above, the model two (main model of the study) is expressed as follows:

$$
\begin{aligned}
& \text { Where: } \\
& \mathrm{EMG}_{\mathrm{it}}=\text { Earnings Management } \\
& \mathrm{JA}_{\mathrm{it}}=\mathrm{Joint} \text { Audit } \\
& \mathrm{AUDIND}_{\mathrm{it}}=\text { Auditor Independence } \\
& \mathrm{AUDSPEC}_{\mathrm{it}}=\text { Auditor Industry Specialization } \\
& \text { AUDTEN }_{\mathrm{it}}=\text { Audit Firm Tenure }
\end{aligned}
$$$$
E M G_{i t}=\beta_{0}+\beta_{1} J A_{i t}+\beta_{2} A_{U D I T E N}+\beta_{3} A_{U U D S P E C}+\beta_{4} A U D I N D_{i t}+\varepsilon_{i t}
$$

\section{Results and Discussion}

The Correlation matrix results for all the variables used in the study are presented in Table 1.

The results in Table 1 above shows Pearson correlation coefficient of the variables used in this study. The Table indicates a positive association between joint audit and earnings management, audit tenure and earnings management, audit specialisation and earnings management and auditor independence and earnings management, but insignificant in all situations.

The results in the Table 2 show the presence of Heteroscedasticity in the panel as indicated by the Bruch Pagan/Cook-Weisberg test for heteroscedasticity Chi of 7.02 with p-value of 0.0081 . This is corrected using OLS (Heteroscedasticity corrected standard errors). The Table 2 also indicates the absence of perfect multi-collinearity among the explanatory variables, as shown by the mean VIF of 9.60. The decision criteria for the Variance Inflation Factor is that a value of 10 and above according to Gujarati [30] and Wooldridge [31] implies the presence of perfect multi-collinearity. The results from Table 2 indicates that the independent variables of model one (beginning loan loss allowances, loan charge off, changes in non-performing loans, and total loans outstanding all scaled by total assets) explained around $93.29 \%$ of the variations in the total loan loss provision (LLP) of listed deposit money banks in Nigeria, from the coefficient of determinations $\left(R^{2}\right.$ value of 0.9329). Table 2 also shows that the model is fit as evident by the F-Statistic of 191.09 which is significant at $1 \%$ level of significance (as indicated by the P-value of 0.0000 ). Therefore, the study measured the earnings management from this regression model, which is the residual of the model (Discretionary Loan Loss Provision).

The study also assesses the audit quality (through joint audit, audit tenure, auditor industry specialization, and auditor independence) in

\begin{tabular}{|l|l|l|l|l|l|}
\hline e(V) & EMG & JA & TENURE & AUDSPEC & AUDIND \\
\hline EMG & 1 & & & & \\
\hline JA & 0.1157 & 1 & & & \\
\hline & -0.3785 & & & & \\
\hline TENURE & 0.0885 & -0.1019 & 1 & & \\
\cline { 2 - 6 } & -0.5012 & -0.4384 & & & \\
\hline AUDSPEC & 0.0151 & 0.0563 & 0.1543 & 1 & 1 \\
\hline & -0.9089 & -0.6693 & -0.239 & & \\
\hline AUDIND & 0.1181 & $-0.2532^{*}$ & $0.2693^{* *}$ & $0.7229^{* * *}$ & 1 \\
\hline & -0.3688 & -0.0509 & -0.0375 & 0 & \\
\hline
\end{tabular}

P-Values in parentheses ${ }^{*},{ }^{* *},{ }^{* * *}$ denote significant at $10 \%, 5 \%, 1 \%$ levels respectively).

Table 1: Coefficient of correlation. 


\begin{tabular}{|l|c|c|}
\hline Variables & Statistics & P-values \\
\hline R- squared & 0.9329 & \\
\hline Adj R-Squared & 0.928 & \\
\hline F-Statistic & 191.09 & 0 \\
\hline Root MSE & 0.90683 & \\
\hline Hettest & 7.02 & 0.0081 \\
\hline Mean VIF & 9.6 & \\
\hline N (Observation) & 60 & \\
\hline
\end{tabular}

Table 2: Summary of regression results: Model One.

\begin{tabular}{|c|c|c|c|}
\hline Variables & Coefficients & $\mathbf{t}$ & P-values \\
\hline JA & 1.054533 & $2.34^{* *}$ & 0.023 \\
\hline AUDSPEC & -0.0302366 & $-2.07^{* *}$ & 0.043 \\
\hline AUDTEN & -0.0078915 & -0.12 & 0.906 \\
\hline AUDIND & 0.6010025 & $2.76^{* * *}$ & 0.008 \\
\hline CONSTANT & -3.744818 & \#VALUE! & 0.018 \\
\hline R Square & 0.1632 & & \\
\hline Adj. R Square & 0.1024 & & \\
\hline F-Statistic & $2.68^{* *}$ & & 0.0409 \\
\hline Root MSE & 0.82953 & & 0.0854 \\
\hline Hettest: Chi & $2.96^{*}$ & & \\
\hline Mean VIF & 1.31 & & 0.3466 \\
\hline Ovtest & 1.13 & & \\
\hline
\end{tabular}

$\left({ }^{*},{ }^{* *},{ }^{* * *}\right.$ Denote significant $10 \%, 5 \%, 1 \%$ levels respectively).

Table 3: Summary of regression results: Model Two.

relation to earnings management. The regression results (for model 2) are presented and evaluated in Table 3:

Tests were performed as required to decide on which regression method best fits the model and data of the study. The Hausman [32] test results recommend the use of Random Effects Regression. The Bruch and Pagan Lagrangian Multiplier test for random effects indicate the absence of significant statistical variance in the panel. Table 3 also shows the absence of perfect multi-collinearity among the explanatory variables, as shown by the mean VIF of 1.31 . The decision criteria for the Variance Inflation Factor are that a value of 10 and above implies the presence of perfect multi-collinearity.

The results in Table 3 show the absence of Heteroscedasticity in the panel as indicated by the Bruch Pagan/Cook-Weisberg test for heteroscedasticity Chi of 2.96 with p-value of 0.0854 . This shows that there is no need for a robust OLS. Table 3 also shows that the independent variables explained around $16.32 \%$ of the variations in the earnings management (measured by discretionary loan loss provisions) of the listed deposit money banks in Nigeria. Table 3 also shows that the model is fit as evident by the F-Statistic of 2.68 which is significant at $5 \%$ level of significance (as indicated by the P-value of 0.0409). Following the fitness of the model, the test of hypotheses is formulated. The coefficients of each of the independent variables in the study are also presented in Table 3. To formulate the regression model,

\section{$\chi_{1}=$ Joint Audit (JA), $\chi_{2}=$ Audit Tenure (AUDTEN).}

$\chi_{3}=$ Auditor Industry Specialization (AUDSPEC, $\chi_{4}=$ Auditor Independence (AUDIND)

$\boldsymbol{\beta} \mathbf{o}=$ Constant and $\mathrm{Y}=$ Earnings Management.

The equation formula is given as $\mathrm{EMG}=\boldsymbol{\beta} \mathbf{o}+\beta \chi_{1}+\beta \chi_{2}+\beta \chi_{3}+\beta \chi_{4}+\varepsilon$ (3.3)

$\mathrm{EMG}=-3.744818+1.054533 \chi_{1}-0.0078915 \chi_{2}-0.03302366 \chi_{3}+$ $0.6010025 \chi_{4}+\varepsilon$

Evaluation of Independent Variables.
The value of the intercept $\boldsymbol{\beta} \mathbf{o}$ is $\mathbf{- 3 . 7 4 4 8 1 8}$ from table above implies that discretionary accruals will be negative when there is no measure of audit quality to serve as an independent variable or when the independent variables are equal to zero. The coefficient of the independent variables is interpreted as follows:

Joint Audit $\left(\boldsymbol{\beta}_{1}=\mathbf{1 . 0 5 4 5 3 3} \mathbf{t}=\mathbf{2 . 3 4}\right.$; and $\left.\mathbf{p}=\mathbf{0 . 0 0 2 3}<0.05\right) \boldsymbol{\beta}_{1}$ is given as the average difference in $Y$ between the category for which joint audit is $=0$ and the category for which $\mathrm{x}=1$. The positive coefficient indicates that there is a positive relationship between joint audit and earnings management. Since joint audit as one of the independent variables identified as a determinant is statistically significant to earnings management, we conclude that joint audit is a significant determinant of earnings management in Nigerian listed deposit money banks.

Audit Specialization $\left(\boldsymbol{\beta}_{2}=-\mathbf{0 . 0 3 0 2 3 6 6} ; \mathrm{t}=-2.07\right.$; and $\mathbf{p}=\mathbf{0 . 0 4 3 < 0 . 0 5 )} . \boldsymbol{\beta}_{3}$ at $\mathbf{- 0 . 0 3 0 2 3 6 6}$ represents the mean change in the earnings management (discretionary accruals) for one unit change in audit specialization while holding all other predictor variables in the model constant. Therefore, for every increase in Auditor specialization, there is a decrease in earnings management. Since auditor industry specialization as one of the independent variables identified as a determinant is statistically significant to earnings management, this study holds that audit specialization has a significant relationship with earnings management in Nigerian listed deposit money banks.

Auditor Independence $\left(\beta_{4}=0.6010025 ; \mathrm{z}=4.96 ; \mathrm{p}\right.$-value at $\mathbf{0 . 0 0 8}<0.01) \beta_{4}$ is 0.6010025 and shows that for every one unit increase in auditor independence, earnings management increases by $\mathbf{0 . 6 0 1 0 0 2 5}$. Since auditor independence as one of the independent variables identified as a determinant is statistically significant to earnings management, we conclude that auditor independence is a significant determinant of earnings management in Nigerian listed deposit money banks.

Audit Tenure $(\beta 2=-0.0078915 ; \mathbf{t}=-\mathbf{0 . 1 2} ; \mathbf{p}=\mathbf{0 . 9 0 6}>\mathbf{0 . 0 5}) \quad \beta_{2}$ at -0.00789533 shows the mean change in earnings management for an increase in audit tenure while holding all other independent variables constant. Therefore, for every unit increase in audit tenure, there is a decrease in earnings management. Since audit tenure as one of the independent variables identified as a determinant is statistically insignificant to earnings management, we conclude that audit tenure is an insignificant determinant of earnings management in Nigerian listed deposit money banks.

\section{Conclusion and Recommendation}

This research concludes that joint audit has a positive influence on earnings management, which in turn means it has minimally detected earning management activities (discretionary accruals). Audit specialization would be instrumental in reducing earnings management in Nigerian listed deposit money banks based on their negative relationship discovered to be significant, as specialized audit firms are employed in banks, earnings management decrease. Even the reputation of the specialized audit firms discourages some managers from earnings management. Audit independence (measured by total audit and non-audit fees received) has a significant positive relationship with earnings management, as managers deliver "honorable" fees and engage auditors in non-audit services to increase familiarity and reduce objectivity in the audit process thereby creating room for earnings management. Shorter audit tenure could result to decreased earnings management. There are more qualitative factors that contribute to audit quality in Nigerian listed deposit money banks. This study concluded that listed deposit money banks in Nigeria. 
Citation: Jayeola O, Agbatogun Taofeek O, Akinrinlola Toluwalase O (2017) Audit Quality and Earnings Management among Nigerian Listed Deposit Money Banks. Int J Account Res 5: 159. doi:10.4172/2472-114X.1000159

\section{References}

1. Lo K (2008) Earnings management and earnings quality. Journal of Accounting and Economics 45: 350-357.

2. Ball $R$, Shivakumar $L$ (2007) Earnings quality at initial public offerings. Journal of Accounting and Economics 45: 324-349.

3. McNichols MF (2002) The quality of accruals and earnings: the role of accrual estimation errors: Discussion. The Accounting Review 77: 61-69.

4. Givoly DC, Hayn K, Katz SP (2010) Does public ownership of equity improve earnings quality? The Accounting Review 85: 195-225.

5. Dechow PM, Ge W, Schrand C (2010) Understanding earnings quality: A Review of the Proxies, their determinants and their consequences. Journal of Accounting and Economics 50: 344-401.

6. Gul FA, Fung, S, Bikki J (2009) Earnings quality: some evidence on the role of auditor tenure and auditors' industry expertise. Journal of Accounting and Economics 47: 265-287.

7. Habbash M (2010) The effectiveness of corporate governance and externa audit on constraining earnings management practice in UK, Theses, Durham University.

8. Inaam Z, Khmoussi H, Fatma Z (2012) Audit quality and earnings management in the Tunisian context. International Journal of Accounting and Financial Reporting 2: 17-27

9. Holm C, Thinggaard F (2012) 'Balancing auditor choices during the transition from a mandatory to a voluntary joint audit system in denmark'.

10. Lesage C, Ratzinger-Sakel N, Kettunen J (2012) 'Struggle over joint audit: On behalf of public interest?' Working Paper.

11. Pouraghajan A, Tabari NAY, Emamgholipour M, Mansourinia E (2013) The effect of audit quality on earnings management: evidence from Iran. International Journal of Basic Sciences and Applied Research 2: 399-404

12. Dechow PM, Sloan RG, Sweeney AP (1997) Detecting earnings management. The Accounting 70: 193-225.

13. Jeong SW, Rho J (2004) Big six auditors and audit quality: the Korean evidence. The International Journal of Accounting 39: 175-196.

14. Abdul RR, Ali FH (2006) Board, audit committee, culture and earnings management: Malaysian evidence. Managerial Auditing Journal 21: 783-804.

15. Memis MU, Cetenak EH (2012) Earnings management, audit quality and legal environment: An international comparison. International Journal of Economics and Financial Issues 2: 460-469.

16. Chen KY, Lin KL, Zhou J (2005) Audit quality and earnings management for Taiwan IPO firms. Managerial Auditing Journal 20: 86-104.
17. Becker CL, DeFond ML, Jiambalvo JJ, Subramanyam KR (1998) The effect of audit quality on earnings management. Contemporary Accounting Research 15: 1-24.

8. Zgarni I, Hlioui K, Zehri F (2012) Audit Quality and Earnings Management in the Tunisian Context. International Journal of Accounting and Financial Reporting 2: 17-33.

19. Reichelt K, Wang D (2010) National and office-specific measures of auditor industry expertise and effects on audit quality. Journal of Accounting Research 48: 647-686.

20. Low KY (2004) The effects of industry specialization on audit risk assessments and audit planning Decisions, The Accounting Review 79I: 201-219.

21. Balsam S, Krishnan J, Yang, JS (2003) Auditor industry specialization and earnings quality. Auditing: A Journal of Practice and Theory 22: 71-97.

22. Aderibigbe $P$ (2005) Auditor's independence and corporate fraud. Journal of Social Sciences 10: 135-139.

23. Louwers JT, Ramsay JR, Sinason HD, Strawser RJ (2007) Auditing and assurance services, Boston: McGraw-Hill.

24. Gray I, Manson S (2000) the Audit Process, Principles, Practice and Cases (1 edn.), United States: Thomson Inc.

25. Hayes R, Dassen R, Schilder A, Wallage P (2005) Principles of Auditing, An Introduction to International Standards on Auditing (1st eds.) Milan: Prentice Hall.

26. Whittington O, Pany K (2004) Principles of Auditing and Other Assurance Services. (14 $4^{\text {th }}$ edn.), New York, NY: McGraw-Hill.

27. Mgbame CO, Eragbhe E, Osazuwa NP (2012) Audit partner tenure and audit quality: an empirical analysis. European Journal of Business and Management 4: 154-162.

28. Siregar SV, Amarullah F, Wibowo A, Anggraita V (2012) Audit tenure, audito rotation and audit quality: The case of Indonesia. Asian Journal of Business and Accounting 5: 55-74.

29. Myers J, Myers L, Omer T (2003) Exploring the term of auditor client relationship and the quality of earnings: A case for mandatory auditor rotation? The Accounting Review 78: 779-799.

30. Gujarati DN (2003) Basic Econometrics. New York: McGrans, Hill//rwin.

31. Wooldridge JRM (2009) Introductory Econometrics: A modern approach $\left(^{\text {th }}\right.$ edn.), Cambridge: USA Cen gage learning.

32. Hausman JA (1978) Specification tests in econometrics. Econometrica 46 1215-11271. 